\title{
Game Edukasi berbasis Android: Urgensi Penggunaan, Pengembangan dan Penguji Kelayakan
}

\author{
${ }^{1}$ Kurnia Muhajarah, ${ }^{2}$ Farida Rachmawati \\ 1,2Fakultas Dakwah dan Komunikasi, UIN Walisongo Semarang, Indonesia, \\ kurniamuhajarah@walisongo.ac.id, faridarachmawati@walisongo.ac.id
}

\section{ARTICLE INFO}

Article History:

Received : 04-09-2019

Revised : 18-11-2019

Accepted : 23-11-2019

Online : 30-11-2019

Keywords:

Game Edukasi;

Android;

Media Pembelajaran

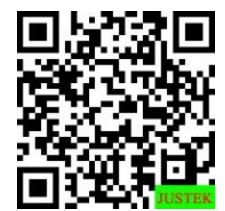

\begin{abstract}
Abstract: The development of information technology today has been able to package the conditions and realities of learning to be more attractive. Educational games are games or fun activities that contain educational content and their use, which is a necessity. This research is a library research. The data was extracted and analyzed in depth using the qualitative theory of Bogdan and Cresswell. The results showed that the ability to absorb each student in learning was strongly influenced by the learning experience, mode, modality and learning style. There are differences regarding this matter, it can be accommodated by the use of educational games as learning media. The use of educational games does not conflict with behaviorism and cognitivism theories. On the other hand, the use of android-based educational games serves to make it easier for students to operate and use them. However, because of its simplicity, the use of educational games must be tested first through strict instruments by experts to be able to meet the marketing standards, test content and maximize its use.
\end{abstract}

\begin{abstract}
Abstrak: Perkembangan teknologi informasi dewasa ini telah mampu mengemas kondisi dan realitas pembelajaran menjadi lebih menarik. Game edukasi merupakan permainan atau aktivitas menyenangkan yang memuat konten pendidikan dan penggunaanya, merupakan sebuah keniscayaan Penelitian ini merupakan penelitian kepustakaan. Data digali dan dianalisis secara mendalam menggunakan teori kualitatifnya Bogdan dan Cresswell. Hasil penelitian menunjukkan bahwa kemampuan daya serap masing-masing peserta didik dalam pembelajaran sangat dipengaruhi oleh pengalaman belajar, modus, modalitas dan gaya belajarnya. Adanya perbedaan mengenai akan hal ini, bisa diakomodir dengan penggunaan game edukasi sebagai media pembelajaran. Penggunaan game edukasi ini tidak bertentangan dengan teori behaviorime dan kogntivisme. Di lain sisi, penggunaan game edukasi berbasis android, berfungsi untuk memudahkan peserta didik dalam pengoperasian dan penggunaannya. Namun demikian, karena kemudahannya, penggunaan game edukasi harus diujilayakkan dahulu melalui instrumen yang ketat oleh para ahli untuk dapat memenuhi standar edar, uji konten dan memaksimalisasi pemanfaatannya.
\end{abstract}

\section{A. LATAR BELAKANG}

Perkembangan teknologi informasi dewasa ini telah mampu mengemas kondisi dan realitas pembelajaran menjadi lebih menarik dan memberikan pengondisian secara adaptif 
dalam proses pembelajaran dimanapun berada, salah satunya adalah model permainan atau game (Kristanto, 2016). Model game dikembangkan berdasarkan pembelajaran yang menyenangkan, dimana peserta didik akan dihadapkan pada beberapa petunjuk dan aturan permainan (Norhan \& Sanjaya, 2016). Game adalah suatu sistem atau program dimana satu atau lebih pemain mengambil keputusan melalui kendali pada objek di dalam permainan untuk suatu tujuan tertentu (Yulia et al., 2019). Dalam bahasa lain, game merupakan aktivitas pelengkap untuk pembelajaran di kelas yang membawa efek positif dan signifikan bagi siswa (Wolfman, 2013)

Game edukasi merupakan permainan atau aktivitas menyenangkan yang memuat konten pendidikan (Sari, et.al, 2014.) dan penggunaanya, merupakan sebuah keniscayaan (Andri, 2017). Hal ini selaras dengan penelitian yang dilakukan oleh Pratama (Pratama et al., n.d.), bahwa sebanyak $91,02 \%$ guru dan peseta didik menunjukkan pendapat yang positif dalam pengadaan game edukasi dalam sebuah pembelajaran sementara $8,98 \%$ responden menyatakan pendapat yang kurang tertariknya dikarenakan game mempunyai pesona adiktif yang dapat membuat pemainnya "kecanduan". Menurut Syamsuar \& Refliyanto (2017), istilah codes of conduct for scientists, academic integrity code dan etika keilmuan (ethic of science) mengantarkan manusia untuk membangun lingkungan yang kondusif dalam pengembangan ilmu, serta moralitas dalam memperoleh dan mendayagunakan ilmu tersebut. (Di \& Revolusi, n.d.).

Berdasarkan fenomena inilah, peneliti menganggap perlu berbagai inovasi kreatif dalam menciptakan game yang memuat konten pendidikan sebagai media pembelajaran. Game edukasi ini akan dapat dimanfaatkan guna mendukung kegiatan belajar mengajar dan menarik minat atau motivasi belajar peserta didik. Penelitian ini bertujuan untuk memperoleh jawaban atas bagaimana urgensi penggunaan game edukasi sebagai media pembelajaran dan bagaimana pengembangan dan pengujian kelayakan game edukasi berbasis android sebagai media pembelajaran.

\section{B. METODE PENELITIAN}

Penelitian ini adalah penelitian kepustakaan (library research) dan bersifat kualitatif dikarenakan penelitian ini menjabarkan data deskriptif dan menelaahnya secara natural (Bogdan and Taylor: 1975). Creswell (2007) mengungkapkan sebagai penelitian yang mengumpulkan informasi yang ciri-cirinya berwujud kata-kata dan bukan rangkaian angkaangka.

\section{HASIL DAN PEMBAHASAN}

1. Urgensi Penggunaan Game Edukasi sebagai Media Pembelajaran: Tinjauan Teori Kerucut Pengalaman Edgar Dale, Modus Belajar Bruner, Modalitas dan Gaya Belajar Bobby dePotter, Teori Belajar Behaviorisme dan Kognitivisme

Kata media adalah bentuk jamak dari medium yang berasal dari bahasa latin medius yang berarti tengah. Dalam bahasa Indonesia, medium dapat diartikan sebagai antara atau selang. Dengan artian, media mengarah pada sesuatu yang mengantar meneruskan informasi (pesan) antara sumber (pemberi pesan) dan penerima pesan yang bertujuan instruksional atau mengandung maksud-maksud pengajaran (Putranti, 2013; Arsyad 2009; Sadiman et.al, 2010). Media memiliki peranan penting dalam proses pembelajaran (Mawarni \& Muhtadi, 2017). Keberadaan media pembelajaran mampu membangkitkan minat belajar, motivasi serta membawa pengaruh psikologis bagi siswa dalam proses belajar mengajar. Media dalam pembelajaran memiliki fungsi sebagai alat bantu untuk memperjelas pesan yang disampaikan guru (Safitri et.al, 2013; General et al., n.d.).

Pentingnya penggunaan media dalam pembelajaran, diperkuat oleh pendapat Edgar Dale yang mengemukakan teori yang kemudian lebih dikenal dengan teori Kerucut 
Pengalaman (Kristanto, 2016). Dalam teori ini Dale (Nurul Farhana, 2017) mengatakan bahwa keberhasilan belajar diukur dengan kadar pengalaman belajar yang diperoleh peserta didik tergantung perlakuannya dalam belajar, baik perlakuan guru atau aktivitas peserta didik ketika belajar Belajar haruslah dilakukan sendiri oleh peserta didik yang. Belajar adalah mengalami, belajar tidak bisa dilimpahkan kepada orang lain. Dale mengemukakan bahwa belajar yang paling baik adalah belajar melalui pengalaman langsung (direct performance), bukan sekadar melihat bagaimana orang menikmati (demonstrating), apalagi sekadar mendengar orang bercerita (telling). Untuk lebih jelasnya dapat dilihat pada Gambar 1.

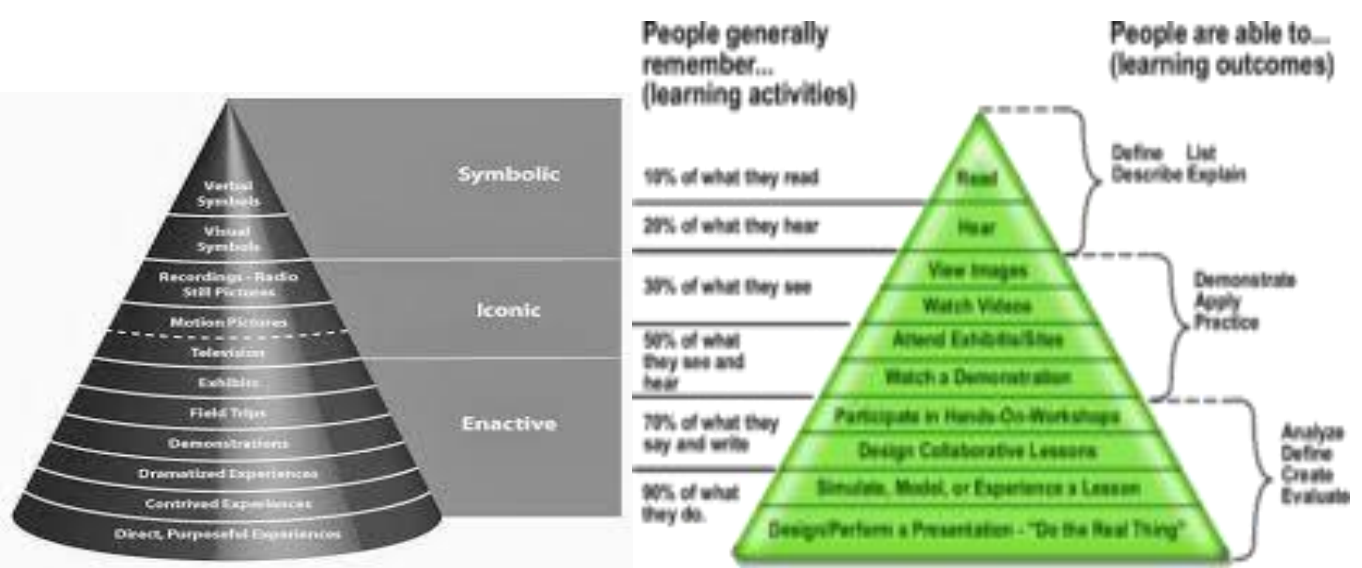

Gambar 1. Teori Kerucut Pengalaman (Cone of Experience as known as Learning Pyramid)

Sumber: Google dan Wikipedia

Itu artinya, kedudukan media cukup penting dalam meningkatkan kadar informasi yang diingat (70\%) dibandingkan dengan pembelajaran melalui metode ceramah (20\%). Pemerolehan pengetahuan dan keterampilan terjadi karena interaksi antara pengalaman baru dengan pengalaman lama (Nurdyansyah, 2017).

Hal ini senada dengan tiga tingkatan modus belajar menurut Bruner (Nurdyansyah, 2017). Pertama adalah pengalaman langsung (enactive) merupakan suatu tahap pengetahuan yang dipelajari secara aktif dengan menggunakan benda-benda kongkrit atau menggunakan situasi yang nyata; kedua adalah pengalaman pictorial/ gambar (iconic) merupakan tahap pengetahuan yang direpresentasikan dalam bentuk bayangan visual (visual imagery), gambar atau piagam yang menggambarkan kegiatan kongkrit atau situasi kongkrit yang terdapat pada tahap enactive; Ketiga pengalaman abstrak atau simbolik yaitu suatu tahap pengetahuan yang direpresentasikan dengan menggunakan simbol-simbol abstrak yang dipakai berdasarkan kesepakatan yang bersangkutan baik berupa simbol verbal lambang maupun lambang-lambang abstrak lainnya. Ketiga tingkat pengalaman ini saling berinteraksi untuk memperoleh pengalaman (pengetahuan, keterampilan atau sikap) yang baru. Kesimpulannya adalah Dale dengan teori kerucut pengalaman merupakan elaborasi yang rinci dari konsep tiga tingkatan Bruner bahwa bahwa semakin nyata objek yang dipelajari, maka semakin konkret pengetahuan yang diperoleh siswa dan semakin tidak langsung pengetahuan diperoleh, maka semakin abstrak pengetahuan siswa (Kasus et al., 2013).

Berkaitan dengan hal tersebut, dalam proses pembelajaran, kemampuan daya serap setiap orang terhadap ilmu dalam pembelajaran sangat dipengaruhi oleh modalitas belajar setiap peserta didik. Dengan mengetahui modalitas belajar maka juga mengenali karakteristik dan gaya belajar peserta didik tersebut. Menurut DePotter (2002), ada tiga modalitas belajar seseorang, yaitu yaitu modalitas visual, auditori atau kinestetik (V-A-K). Peserta didik visual saat belajar cenderung melalui apa yang mereka lihat. Peserta didik dengan kemampuan auditorial saat belajar cenderung dari apa yang mereka dengar 
sedangkan orang kinestetik saat belajar cenderung lewat gerak ataupun sentuhan. Setiap orang belajar dengan menggunakan ketiga modalitas ini, pada tahapan tertentu, kebanyakan orang lebih cenderung pada salah satu di antara ketiga modalitas belajar ini. Duckett dan Tatarkowski (2005) telah memberikan instrumen terstandar untuk identifikasi gaya belajar V-A-K tersebut. Data dari survei gaya belajar yang lebih aktual dan dominan dapat dijadikan acuan empiris untuk merancang bentuk media belajar yang sesuai karakteristik mayoritas calon penggunanya (Http://Journal.Uny.Ac.Id/Index.Php/Jitp, 2017).

Di lain sisi, pengembangan media pembelajaran membutuhkan penerapan prinsipprinsip pembelajaran itu sendiri, sehingga media yang dikembangkan dapat dikatakan sebagai aplikasi ilmiah. Pengembangan media belajar berbasis game edukasi ini memiliki dua landasan penekanan teori belajar, yaitu teori belajar behavioristik dan kognitivistik. Menurut behaviorisme, pembelajaran paling fundamental berasal dari pembentukan asosiasi-asosiasi antara stimulus dan respon yang memberikan manifestasi berbentuk perilaku. Sedangkan menurut teori kognitivisme, Bandura menyatakan bahwa manusia adalah organisme dinamis dalam mengolah informasi serta berperan sebagai makhluk sosial (Hergenhahn \& Olson, 2012).

Dari teori tersebut diuraikan prinsip-prinsip untuk aplikasi pembelajaran yang sesuai pada perancangan dan pengembangan produk. Bentuk-bentuk yang ditekankan dari penerapan prinsip-prinsip teori belajar behavioristik (Joyce dalam Pratama, 2017), dalam Pratama diantaranya (a) belajar dengan ketuntasan, (b) pembelajaran langsung (direct instruction), (c) pemberian penguatan (reinforcement) yang tepat, (d) pembelajaran berbasis komputer (CBI), serta (e) pembelajaran terprogram (Skinner). Sedangkan bentukbentuk yang ditekankan dari penerapan prinsip-prinsip teori belajar kognitivistik diantaranya (a) pembelajaran resepsi bermakna (Ausubel), (b) prinsip pengorganisasian (Gestalt), (c) perangkat organisator pengantar ekspositoris, (d) modeling simbolis (Bandura), serta (e) pengolahan informasi visual (Wolfe).

\section{Pengembangan dan Penguji Kelayakan Game Edukasi berbasis Android sebagai Media Pembelajaran}

Ponsel cerdas (smartphone) adalah perangkat yang digemari oleh masyarakat di berbagai daerah saat ini. Ponsel cerdas merupakan perangkat gerak yang memiliki kecanggihan lebih dari ponsel biasa. Beberapa sistem operasi yang digunakan pada ponsel cerdas diantaranya Android, Blackberry, IOs, Windows Phone, dll. Dari kesemuanya, Android adalah yang paling banyak digunakan. Android populer juga karena dipakai beberapa produsen internasional seperti Samsung, Lenovo, HTC, dan Sony. Produsen lokal seperti Mito, Evercross, Advan, dan Smartfren juga turut memanfaatkannya (Pratama et al., n.d.).

Android telah memimpin pasar ponsel cerdas dengan jumlah pengguna tertinggi. International Data Corporation (2016) menunjukkan bahwa Global Smartphone OS Marketstore pada tahun 2012 sampai 2015 dikuasai Android dengan persentase 79,2\%, Apple/IOs 13,8\%, WindowsPhone 2,9\%, Blackberry 2,1\%, dan sistem operasi lain 2,1\%. Lebih dari 30 juta perangkat Android telah dimanfaatkan oleh pengguna ponsel cerdas, Android secara pasti menjadi teknologi ponsel perdas yang selangkah lebih maju (Finnegan: 2013).

Secara potensial, game digital android lebih praktis, menarik, dan berkonten ringkas sehingga dapat memperluas kesempatan belajar penggunanya. Selain itu, game digital android merupakan sajian produk multimedia karena terdapat elemen teks, gambar, suara, animasi, dan interaktivitas. Game dapat digunakan untuk mengeksplorasi dan membangun konsep disertai hubungan konteks yang otentik (Woo: 2014). 
Pada tingkatan yang lebih luas, psikologi perkembangan dipengaruhi oleh situasi lingkungan, harus diakui bahwa game digital telah menjadi aspek yang tidak terpisahkan dari kehidupan anak-anak dan remaja saat ini (Blumberg dan Fisch: 2013). Melaju dari tahun 2010, ponsel cerdas telah menjadi bentuk baru era mobile gaming. Menurut Zechner: 2011, game-game ponsel cerdas telah mampu bersaing dengan perangkat game konsol genggam seperti Nintendo DS dan Playstation portable (Http://Journal.Uny.Ac.Id/Index.Php/Jitp, 2017)

Dalam mengembangkan produk game digital, dibutuhkan aplikasi pembangun (game engine) yang sesuai dengan tujuan serta memiliki performansi handal. Dalam beberpa pemakaian, Unity adalah software yang terpilih. Unity merupakan aplikasi pembangun pertama yang ideal untuk mengembangkan kreasi game dengan berbagai fitur tinggi, serta memiliki kemampuan authoring beberapa platform yang berbeda. (Blackman: 2013). Unity merupakan aplikasi pembangun game 3D yang memungkinkan pembuatan game bergaya 2D (Finnegan: 2013). Versi terakhir telah mendukung pengembangan untuk platform iOs, Android, Windows, Blackberry 10, OS X, Linux, peramban web, PlayStation, Xbox. Unity dan android sangat berpotensi untuk dipadukan. Unity dapat menangani projek dan aset-aset game dengan baik (Spector: 2012).

Game ponsel cerdas Android yang dikembangkan sebagai game edukasi digital dapat memuat fitur-fitur yang berpotensi memberikan pengalaman permainan dan pembelajaran secara menarik dan berkelanjutan. Blumberg dan Fisch (2013) meringkas beberapa fitur tersebut, diantaranya (a) membuat penasaran (curiosity), (b) adanya tantangan (challenge), (c) menyertakan khayalan (fantasy), (d) adanya timbal balik (interactivity), (e) adanya kendali pengarahan (agency or control), (f) adanya keterkaitan karakter dan pemain (identity), (g) adanya umpan balik dari aktivitas (feedback), serta (h) adanya keterlibatan pribadi (immersion). Sehingga fitur-fitur tersebut sesuai pada paradigma belajar abad 21.

Desain strategi pemanfaatan game edukasi biasa dilakukan dengan dua cara, yaitu memainkan game dalam pengaturan pembelajaran atau belajar langsung melalui game (Filsecker dan Kerres: 2014). Game edukasi merupakan bentuk permainan yang dirancang untuk membantu pebelajar mencapai tujuan pembelajaran tertentu dan sekaligus memberikan motivasi (Clark \& Mayer, 2011; Surahman, 2019; Mawarni \& Muhtadi, 2017)

Game dapat dikategorikan sebagai salah satu format sajian multimedia pembelajaran. Ditinjau dari model game secara khusus, Ulicsak \& Williamson (2011) memberikan kategori secara contoh, diantaranya (s) platform games, (b) sports games, (c) serious games, (d) casual games, (e) edutainment (educational games), (f) RPG (role playing games), dst. Jenis game edukasi sebenarnya lebih menekankan pada rancangan fungsional, bukan jenis pada rancangan teknis (Metode et al., 2016).

Menurut Ulicsak \& Wright (2010), game edukasi akan bergantung pada ketepatan rumusan pedagogis, mekanisme permainan, dan integrasi konten (Pratama, 2017). Reddi (Mawarni \& Muhtadi, 2017) telah merancang kisi-kisi penilaian multimedia pembelajaran melalui empat aspek, yaitu (1) efektivitas pembelajaran, (2) nilai hiburan, (3) kenyamanan penggunaan, dan (4) fitur desain. Aspek-aspek tersebut sesuai untuk kisi-kisi instrumen penilaian dari persepsi pengguna.

Alessi dan Trollip dikutip oleh Mawarni dan Muhtadi (2017) menguraikan beberapa aspek yang perlu dijadikan standar penilaian tersebut. Diantaranya (a) subjek materi, (b) informasi tambahan, (c) pertimbangan sikap, (d) tampilan antarmuka, (e) navigasi, (f) pedagogi (pembelajaran), (g) fitur tersembunyi, (h) robustness, dan (i) materi pendukung. Susunan aspek-aspek tersebut dapat dikembangkan lebih lanjut menjadi kisi-kisi instrumen penilaian kelayakan multimedia pembelajaran oleh ahli bidang terkait. Ahli materi dapat meliputi aspek (a) subjek materi, (b) pembelajaran, (c) materi pendukung, dan (d) pertimbangan sikap. Sedangkan ahli media meliputi aspek (a) tampilan antarmuka, 
(b) navigasi, (c) informasi tambahan media, (d) pembelajaran, serta (e) pertimbangan sikap. Selain mempertimbangkan kelayakan ahli bidang materi dan media pembelajaran, sudah semestinya dilakukan uji kelayakan dari sisi calon pengguna media itu sendiri. (Mawarni \& Muhtadi, 2017)

\section{SIMPULAN DAN SARAN}

Simpulan dari penelitian ini adalah (1) kemampuan daya serap masing-masing peserta didik dalam pembelajaran sangat dipengaruhi oleh pengalaman belajar, modus, modalitas dan gaya belajarnya. Adanya perbedaan mengenai akan hal ini, bisa diakomodir dengan penggunaan game edukasi sebagai media pembelajaran. Penggunaan game edukasi ini tidak bertentangan dengan teori behaviorime dan kogntivisme; (2) penggunaan game edukasi berbasis android, berfungsi untuk memudahkan peserta didik dalam pengoperasian dan penggunaannya. Namun demikian, karena kemudahannya, penggunaan game edukasi harus diujilayakkan dahulu melalui instrumen yang ketat oleh para ahli untuk dapat memenuhi standar edar, uji konten dan memaksimalisasi pemanfaatannya. Saran penulis adalah perlu adanya kolaborasi diantara ahli Pendidikan, ahli IT, ahli Edu-Tech dalam pembuatan game edukatif, sekaligus ujian kontennya. Kolaborasi para ahli, akan membantu peserta didik dalam pembelajarannya.

\section{REFERENSI}

\& Wolfman, L. S. B. A. (2013). Paradigma Pendidikan Bermutu Berbasis Teknologi Pendidikan. In Journal of Chemical Information and Modeling (Vol. 53, Issue 9).

Andri, R. M. (2017). Peran dan Fungsi Teknologi Dalam Peningkatan Kualitas Pembelajaran. Jurnal Ilmiah Research Sains, 3(1), 122-129. http://www.jurnalmudiraindure.com/wp-content/uploads/2017/04/Peran-DanFungsi-Teknologi-Dalam-Peningkatan-Kualitas-Pembelajaran.pdf

Arsyad, Azhar. (2009). Media Pembelajaran. Jakarta: Rajawali Pers.

Bogdan, Robert and Steven J. Taylor. (1975). Introduction to Qualitative Research Methods, New York

Blackman, S. (2013). Beginning 3D game development with Unity 4: All-in-one, multiplatform game development. New York: Apress Media LLC.

Blumberg, F. C., \& Fisch, S. M. (2013). Introduction: digital games as a context for cognitive development, learning, and developmental research. New Directions for Child and Adolescent Development, https://doi.org/10.1002/cad.20026

Clark, R. C., \& Mayer, R. E. (2011). Elearning and the science of instruction: Proven guidelines for consumers and designers of multimedia learning. San Francisco USA: Pfeiffer.

Creswell, John W. (2007). Qualitatif Inquiry and Research Design: Chosing Among Five Approaches, Second Edition, London: Sage Publications

DePotter, Bobby. 2002. Quantum Learning: Unleashing the Genius in You. New York: Dell Publishing

Di, I., \& Revolusi, E. R. A. (n.d.). Pendidikan Dan Tantangan Pembelajaran Berbasis Teknologi Informasi Di Era Revolusi Industri 4.0 Syamsuar 1, Reflianto 2.

Duckett, I., \& Tatarkowski, M. (2005). Practical strategies for learning and teaching on vocational programmes. London: Learning and Skills Development Agency (LSDA).

Filsecker, M., \& Kerres, M. (2014). Engagement as a volitional construct. Simulation \& Gaming, 45(4-5). https://doi.org/10.1177/10468781145 53569

Finnegan, T. (2013). Unity Android Game Development by Example Beginner's Guide. Birmingham UK: Packt Publishing

General, D., Mursyidah, H., Surabaya, U. M., Java, E., Board, E., Hidayatullah, A., Surabaya, 
U. M., Java, E., Ummah, I., Hasyim, U., Java, E., Shoffa, S., Surabaya, U. M., Java, E., Ningsih, W., Malang, P. N., Java, E., Rumite, W., Lampung, U., ... Java, E. (n.d.). No Title.

Hergenhahn, B. R., \& Olson, M. H. (2012). Theories of learning. (Terjemahan Tribowo B.S.). Jakarta: Kencana Prenada Media

International Data Corporation. (2016). Smartphone OS market share, 2015 Q1. Retrieved January 2, 2016, from http://www.idc.com/prodserv/smar tphone-osmarket-share.jsp.

Joyce, B. R., Weil, M., \& Calhoun, E. (2015). Models of teaching. New Jersey: Pearson Education

Kasus, S., Kelas, S., \& Smpn, I. X. (2013). Jurnal Teknologi Informasi \& Pendidikan VOL . 6 NO . 2 September 2013 ISSN : 2086 - 4981 VOL . 6 NO . 2 September 2013. 6(2), 106118.

Kristanto, A. (2016). Aplikasi teknologi pendidikan di sekolah. Jurnal Teknologi Pendidikan, 4, 13-16.

Mawarni, S., \& Muhtadi, A. (2017). Pengembangan digital book interaktif mata kuliah pengembangan multimedia pembelajaran interaktif untuk mahasiswa teknologi pendidikan. Jurnal Inovasi Teknologi Pendidikan, 4(1), 84. https://doi.org/10.21831/jitp.v4i1.10114

Metode, I., Additive, S., Pada, W., Pendukung, S., Pemilihan, K., Bahan, P., Di, B., Kimia, A., Estimasi, R., Dengan, B., Cocomo, T., Dan, I. I., Fuzzy, N., Kasus, S., Informasi, S., Sakit, R., Ting, P., Polusi, K. A. T., Di, U., ... Surabaya, S. (2016). Game Edukasi Sebagai Media Pembelajaran Pendidikan Anak Usia Dini. 1.

Norhan, L., \& Sanjaya, L. (2016). Aplikasi Pembelajaran Menyusun Ayat Sebagai Metode Menghafal Al-Qur'an (Juz 30). Jurnal Online Informatika, 1(2), 87-91. https://doi.org/10.15575/join.v1i2.32

Nurdyansyah, N. (2017). Sumber Daya dalam Teknologi Pendidikan. Universitas Negeri Surabaya, 1-22. http://eprints.umsida.ac.id/1625/1/Sumber Daya dalam Teknologi Pendidikan.pdf

Nurul Farhana. (2017). Peranan Teknologi Dalam Pembelajaran Abad Ke-21. Reasearch Gate, October. https://www.researchgate.net/publication/320555649

Pratama, L. D., Bahauddin, A., \& Lestari, W. (n.d.). Game Edukasi : Apakah membuat belajar lebih menarik?

Pratama, Ujang Nendra dan Haryanto. (2017). Pengembangan Game Edukasi berbasis Android tentang Domain Teknologi Pendidikan, Jurnal Inovasi Teknologi Pendidikan. 4 (2). Oktober, http://journal.uny.ac.id/index.php/jitp

Putranti, N. (2013). Cara Membuat Media Pembelajaran Online. 2(2), 139-147.

Reddi, U. V., et.al. (2003). Educational multimedia: A handbook for teacherCommonwealth Educational Media Centre for Asia (CEMCA)

Sadiman, Arief. S, et.al. (2010). Media Pendidikan Pengertian, Pengembangan dan Pemanfaatan. Jakarta: Rajawali Pers

Safitri, Melani, et.al. (2013). Pengembangan Media Pembelajaran Matematika Pokok Bahasan Segitiga menggunakan Macromedia Flash untuk Siswa Kelas VII SMP. Indonesian Jurnal on Computer Science. Vol. 10 (3)

Sanjaya, W. (2012). Perencanaan dan Desain Sistem Pembelajaran. Jakarta: Kencana

Sari, W, et.al. (2014). Pengembangan Game Edukasi Kimia Berbasis Role Playing Game (RPG) pada Materi Struktur Atom sebagai Media Pembelajaran Mandiri untuk Siswa Kelas X SMA di Kabupaten Purworejo. Jurnal Pendidikan Kimia (JPK). Vol 3(2)

Spector, J. M. (2012). Foundations of educational technology: Integrative approaches and interdisciplinary perspectives. New York USA: Routledge. 
Surahman, E. (2019). Integrated Mobile Learning System (Imoles) Sebagai Upaya Mewujudkan Masyarakat Pebelajar Unggul Era Digital. JINOTEP (Jurnal Inovasi Dan Teknologi Pembelajaran) Kajian Dan Riset Dalam Teknologi Pembelajaran, 5(2), 5056. https://doi.org/10.17977/um031v5i22019p050

Ulicsak, M. and Williamson, B. (2011). Computer games and learning: A handbook. London: Futurelab

Ulicsak, M., \& Wright, M. (2010). Games in education: serious games. Bristol: Futurelab.

Woo, J.-C. (2014). Digital game-based learning supports student motivation, cognitive success, and performance outcomes. Educational Technology \& Society, 17(3), 291307.

Yulia, Y., Purba, N. M. B., \& Nasir, J. (2019). Aplikasi Game Edukasi Matematika Berbasis Android. Indonesian Journal of Computer Science, 8(2), 101-112. https://doi.org/10.33022/ijcs.v8i2.196 